The potential of extract of leaves and flowers ... (Indriyani Nur)

\title{
THE POTENTIAL OF EXTRACT OF LEAVES AND FLOWERS OF Lantana camara Linn. AS AN ANTIBACTERIAL FOR CATFISH (Clarias gariepinus) INFECTED BY Aeromonas hydrophila
}

\author{
Indriyani Nur", Afiyfah Fitriani, and Asnani \\ Fisheries Department, Fisheries and Marine Science Faculty, Haluoleo University, \\ Indonesia Southeast Sulawesi 93232, Indonesia
}

\begin{abstract}
Freshwater catfish culture has been hampered by bacterial diseases. One of the agents of the bacterial disease is Motile Aeromonas Septicemia (MAS). The application of synthetic antibiotics has had some disadvantages such as bacterial resistance and undegradable in water. One of the potential antibacterial herbs is Lantana camara. Information of Lantana as an antibacterial on catfish is still limited. Therefore, the experiment of utilization of Lantana as an antibacterial for catfish should be conducted. The experiment was carried out to evaluate the potential of Lantana extract as an antibacterial of A. hydrophila for catfish. The completely randomized design was applied consisting of four treatments using two parts of the plant, leaves and flowers. The treatments were: $A=1,000 \mathrm{ppm}$ of leaves; $B=2,000 \mathrm{ppm}$ of leaves; $C=1,000 \mathrm{ppm}$ of flowers; $\mathrm{D}=2,000 \mathrm{ppm}$ of flowers), and control. Lantana extracts were diluted into each culture media which had been infected with $A$. hydrophila. Several factors were observed in this experiment such as prevalence with of MAS disease, survival rate, percentage of haematocrites and total of leukocytes of fish blood. The results showed that the fish treated with 2,000 ppm of flowers extract had a lower in prevalence of MAS disease and higher in survival rate than those treated with 1,000 ppm; 2,000 ppm of leaves; and 1,000 ppm of flowers, respectively. However, percentage of haematocrytes and total of leucocytes was not influenced by the extracts from different parts of Lantana plant. In conclusion, 2,000 ppm of Lantana flowers extract might be useful as an antibacterial of A. hydrophila for catfish culture.
\end{abstract}

KEYWORDS: Aeromonas hydrophila, antibacterial, catfish, Lantana camara

\section{INTRODUCTION}

Catfish (Clarias gariepinus) has been intensively cultured in Indonesia. However, one of the problems causing the declining of catfish productions over the last several years was infectious diseases. Diagnostic laboratory evaluations have revealed three bacterial agents thought to be the primary cause of diseases in catfish: Aeromonas hydrophila,
Edwardsiella tarda and a yet- to- be classified variety of myxobacteria (CTSA Publication, 1996). One of these diseases, Motile Aeromonas Septicemia (MAS), is an infection caused by Aeromonas bacteria, the outbreaks occur in fish that are immunocompromised by other factors, such as poor water quality, excessive crowding and handling (FrancisFloyd, 2002).

\# Corresponding author. Aquaculture Department, Faculty of Fisheries and Marine Science Haluoleo University, Southeast Sulawesi 93232, Indonesia. Tel.: + 624013193782

E-mail address: 
Treatments with antibiotic have been employed to treat MAS disease in fish, but researchers found that it was not effective in treating MAS diseases due to environmental pollution and bacterial resistance. There is the evidence that improper use or over use of antibiotics increases the chance for resistant strains to appear (Hawke et al., 1998). Application of erythromycin $(28.9 \%$, chloramphenicol $(28.9 \%$, and potentiated sulphonamide $(20.5 \%$ has become resistance to this bacteria (Angka, 1997). Moreover, it is currently illegal to use these medications for catfish sold for human consumption in several countries. In addition, the benefits of these medications are often temporary, and mortalities often come back to the previous levels if their uses are discontinued. For these reasons, researchers have generally moved away from the use of antibiotics as a cure for bacterial infections in catfish culture and instead they have sought to develop other methods to combat this illness.

Alternatively, bioactive natural compounds for the therapy treatment that are relatively safe and effective for fish diseases have been done and they are becoming popular. Side effects of these treatments are less than drugs or synthetic substances, and it is cheaper. One of these bioactive substances comes from herb, such as Lantana camara. Some research results have reported the success in treating several human diseases by using this herb. Leaves and flowers of Lantana contain bioactive substances. Wahab (2004) conducted phytochemical investigations on the chemical constituents of the aerial parts of $L$. camara. The results provided the earlier contributions for the chemistry and pharmacology of the genus Lantana.

L. camara is a large evergreen strongsmelling herb, native plant to tropical America, but now it can be found in many parts of Indonesia by the local name of "tahi ayam or tembelekan". All parts of this plant have been used traditionally for several ailments throughout the world. The leaves are used as an antitumoral, antibacterial and antihypertensive agent for human (Taoubi et al., 1997). The root of this plant is used for the treatment of malaria, rheumatism and skin rashes (Chharba et al., 1993).

Although herbal medicines in general are safer than modern drugs, they are still suspected to have potential toxicity effects. The side effects of herbal medicines can be reduced with the use of proper materials, accurate dose, usage time, way of usage, analysis information, and without abusing the herbal medicines itself. The accuracy of materials determines the effect of herbal medicines. Information which is not supported by adequate basic knowledge and suffcient study can cause harm on the use of traditional drugs. Therefore, this study investigated the ability of Lantana extraction to inhibit the pathogenic activity of $A$. hydrophila by in vivo assays on catfish. These results demonstrated the potential of the use Lantana extraction in the management of $A$. hydrophila infection in aquaculture.

\section{MATERIALS AND METHODS}

The work was carried out at the Laboratory of Microbiology, Department of Biology, Faculty of Mathematics and Natural Science for extraction stage and at Fisheries Laboratory, Department of Fisheries, Faculty of Fisheries and Marine Science, Haluoleo University, Kendari for fish rearing from June to August 2008.

\section{Extraction of Lantana}

Fresh leaves and flowers of Lantana were cleaned and dried for 3 days by air-drying, then, the dried leaves and flowers were separately blended for 15 minutes to obtain the powder. Powder (100 grams) was then extracted with chloroform for 24 hours. The mixture was then filtered using Whatman filter paper No.42. The filtrate was dried using rotary evaporator at $50^{\circ} \mathrm{C}$, afterwards, the liquid-solid extraction was then dried using an oven at $50^{\circ} \mathrm{C}$ producing a dry powder or crude extract (Modification procedure of Harborne, 1996).

\section{Bacteria and artificial infection}

A. hydrophila isolate (collected from Fish Quarantine Station at Wolter Monginsidi, Kendari) was grown on triptyc soy agar medium at $28^{\circ} \mathrm{C}$ and in triptyc broth previously shaked at $200 \mathrm{rpm}$, at $28^{\circ} \mathrm{C}$. Cells were then pelleted. A dilution series in phosphate- buffered saline of the concentrated cell bacteria prepared as a concentration of $10^{7} \mathrm{cfu} \mathrm{mL}^{-1}$, was used to inoculate the healthy catfish with size of $15-17 \mathrm{~cm}$ in length by intraperitoneal injection with a dose of $0.1 \mathrm{~mL}$ per fish. Following inoculation, the fish were observed for gross behavioural changes, including the pre- 
The potential of extract of leaves and flowers ... (Indriyani Nur)

sence of expected symptoms, every 2 hours for up to 24 hours before giving treatment by immersion in Lantana extract dilution.

\section{In vivo Antibacterial Test}

Groups of 5 infected fish were used per treatment. Fish were immersed in Lantana extract dilution for 1 hour in different concentrations; $A=1,000$ ppm of leaves extract; $B=$ $2,000 \mathrm{ppm}$ of leaves extract; $C=1,000 \mathrm{ppm}$ of flowers extract; $D=2,000$ ppm of flowers extract, and $\mathrm{E}=$ control (a fish group immersed in phosphate- buffered saline). Every treatment was repeated 3 times and the research was arranged in completely randomized design. Following the treatment, the fish were transferred to normal media and then observed for recovery symptom changes and blood condition for up to 12 days.

\section{Prevalence and Survival Rate}

Prevalence Rate is calculated by formula:

$\mathrm{PR}=$ (the number of affected fish with symptom/ the number of all of fish) $\times 100 \%$

Potency of Lantana extract is expressed in terms of Survival Rate (SR) as follows:

$\mathrm{S}=$ (the number of fish at the end $/$ the number of fish at the beginning) $\times 100 \%$

\section{Haematocrit and Leukocyte Rate}

Blood was taken by a syringe with EDTA anticoagulant through caudal artery at the posterior side of the fish body. Blood was then homogenized by a roller mixer before measured using auto hematology analyzer. It was conducted at the Clinic Laboratory, General Hospital, Kendari.

\section{Statistical Analysis}

At the end of the observation, the prevalence of symptom rate, survival rate, haematocrit, and leukocyte rate of blood were calculated; SPSS for Windows (SPSS ver.11.) was used to perform the analyses.

\section{RESULTS}

\section{Prevalence of MAS disease on catfish}

Different alphabet symbols were used to depict the statistical differences at $\mathrm{P}=0.05$

\section{Survival rate of catfish}

Different alphabet symbols were also used to depict the statistical differences at $\mathrm{P}=0.05$

\section{Haematocrit Rate}

Different alphabet symbols were used to state the significant differences at $P=0.05$

\section{Leucocyt Rate}

Different alphabet symbols were used to state the statistical differences at $\mathrm{P}=0.05$

\section{DISCUSSION}

The use of Lantana extract with different doses and parts was examined on catfish in order to cure MAS disease. A day after giving artificial infection, all fish exhibited symptoms as the evidence of the virulence of this pathogenic A. hydrophila strain. Skin ulcers occurred at any site on the affected fish and were surrounded by distinctive skin lesions appeared as large red (hemorrhagic). Several observations gave clues to what was occurred during A. hydrophila infections. They possessed special properties which were enable them to cause more serious disease outbreaks. Markov et al. (2007) stated that these bacteria have a gene called Aerolysin Cytotoxic Enterotoxin (ACT) which produces toxin causing skin damage. After giving Lantana extraction post infection stage, these fish recovered from the symptoms, and finally became normal at the end of the research.

In this study, a simple extraction was performed to obtain a crude extract. A complated examination was conducted by Wahab (2004), where compounds such as; Lantanoside, Lantanone, Methyl ursoxylate, Lancamaric acid, Ursoxy acid, Ursangilic acid, Ursethoxy acid, Camangelogyl acid, Methlcamaralate, Camangeloyl acid, and Camarolide were found. It is assumed that these bioactive compounds have strong influence on the recovery of the treated catfish. In addition, the results obtained from Raghu et al. (2004) study showed that the extract of the leaf of L. camara was cytotoxic in nature and might possess antitumor activity. The cytotoxic activity might be due to the presence of toxic lantanoids and alkaloids from this plant. The plant needs further investigation to identify the active principles and the nature of the antitumor activity. 
Based on the research, immersion treatments using leave and flower extracts showed significant differences than that of the control. The infectious fish immersed in the Lantara crude extract was able to recover. Twelve days after the treatment, the prevalence rates of MAS disease of the fish immersed with 1,000 ppm of leaves; 2,000 ppm of leaves; 1,000 ppm of flowers; and 2,000 ppm of flowers were about $40 \%$ 46.7\% 33.3\% $13.3 \%$ respectively, while the prevalence rate of MAS disease of the control group was $100 \%($ Table 1 ). Similarly, infectious fish immersed in the Lantana crude extract was able to survive. Twelve days after the treatment, the survival rates of fish immersed with $1,000 \mathrm{ppm}$ of leaves; $2,000 \mathrm{ppm}$ of leaves; 1,000 ppm of flowers; and 2,000 ppm of flowers were about $80 \%$ 73.3\% 100\% 100\% respectively, while the survival rate of the control group was $73.3 \%($ Table 2 ).

The obtained Lantana extract is also efficacious in increasing immunity against Aeromonas infection in catfish, as shown by higher haematocrite and leukocyte rates of the treated fish in comparison with the control fish after bacterial infection (Table $3 \& 4$ ). Therefore, the Lantana extract can be considered as a proper medication with no side effects observed to treat A. hydrophylla infection. This results suggest that this crude extract can provide a high level of recovery post infection especially for 2,000 ppm of flowers, and may be beneficial to be used in the aquaculture industry.

Table 1. Prevalence rate of MAS disease (\%) on catfish (C. gariepinus) at the end of research period

\begin{tabular}{lc}
\hline \multicolumn{1}{c}{ Extract treatments } & Prevalence rate \pm S.D. \\
\hline A 1,000 ppm of leaves extract & $40.0 \pm 20.0^{\mathrm{ab}}$ \\
B 2,000 ppm of leaves extract & $46.7 \pm 11.5^{\mathrm{b}}$ \\
C 1,000 ppm flowers of extract & $33.3 \pm 23.1^{\mathrm{ab}}$ \\
D 2,000 ppm flowers of extract & $13.3 \pm 11.5^{\mathrm{a}}$ \\
E Control & $100.0 \pm 0.0^{\mathrm{c}}$ \\
\hline
\end{tabular}

Table 2. Percentage of survival rate of catfish (C. gariepinus) at the end of research period

\begin{tabular}{lc}
\hline \multicolumn{1}{c}{ Extract treatments } & Prevalence rate \pm S.D. \\
\hline A 1,000 ppm of leaves extract & $80.0 \pm 20.0^{\mathrm{ab}}$ \\
B 2,000 ppm of leaves extract & $73.3 \pm 11.5^{\mathrm{b}}$ \\
C 1,000 ppm flowers of extract & $100.0 \pm 0.0^{\mathrm{a}}$ \\
D 2,000 ppm flowers of extract & $100.0 \pm 0.0^{\mathrm{a}}$ \\
E (Control) & $73.3 \pm 11.5^{\mathrm{b}}$ \\
\hline
\end{tabular}

Table 3. Haematocrit rate of catfish (C. gariepinus) at the end of research period

\begin{tabular}{lc}
\hline \multicolumn{1}{c}{ Extract treatments } & Haematocrit rate \pm S.D. \\
\hline A 1,000 ppm of leaves extract & $23.8 \pm 2.9^{\mathrm{a}}$ \\
B 2,000 ppm of leaves extract & $23.7 \pm 0.4^{\mathrm{a}}$ \\
C 1,000 ppm flowers of extract & $25.9 \pm 0.6^{\mathrm{a}}$ \\
D 2,000 ppm flowers of extract & $27.6 \pm 6.2^{\mathrm{a}}$ \\
E (Control) & $14.5 \pm 1.5^{\mathrm{b}}$ \\
\hline
\end{tabular}


Table 4. Leukocyte Rate of catfish (C. gar iepinus) at the end of research period

\begin{tabular}{lc}
\hline Extract treatments & Haematocrit rate \pm S.D. \\
\hline A 1,000 ppm of leaves extract & $204.8 \pm 21.6^{\mathrm{a}}$ \\
B 2,000 ppm of leaves extract & $210.1 \pm 4.2^{\mathrm{a}}$ \\
C 1,000 ppm flowers of extract & $220.1 \pm 1.3^{\mathrm{a}}$ \\
D 2,000 ppm flowers of extract & $224.1 \pm 26.5^{\mathrm{a}}$ \\
E (Control) & $166.8 \pm 5.4^{\mathrm{b}}$ \\
\hline
\end{tabular}

\section{CONCLUSIONS}

The results of this study have shown that the extract of different parts of L. Camara showed a potential antibacterial activity to supress $A$. hydrophila infection with recommended dose of 2,000 ppm of flowers extract.

\section{ACKNOWLEDGENT}

The contributions of La Ode Baytul Abidin to this study are gratefully acknowledged.

\section{REFERENCES}

Angka, S.L. 1997. Antibiotic Sensitivity And Pathogenicity of Aeromonas And Vibrio Isolates in Indonesia, Diseases in Asian Aquaculture III. Fish Health Section, Asian Fisheries Society, Manila.

Chharba, S.C., Mahunnah, R.L.A., \& Mshiu, E.N. 1993. Plants used in traditional medicine in eastern Tanzania. J. Ethnopharmacol, 39: 83- 103.

CTSA Publication. 1996. Bacterial Diseases in Chinese Catfish. Center for Tropical and Subtropical Aquaculture Publication No. 122. The Oceanic Institute. Hawaii.
Francis- Floyd, R. 2002. Aeromonas Infections. The Fisheries and Aquatic Sciences Department, Florida Cooperative Extension Service, Institute of Food and Agricultural Sciences, University of Florida. http:// edis.ifas.ufl.edu. [20 March 2009].

Harborne, J.B. 1996. Metode Fitokimia. ITB Press. Bandung.

Hawke, J.P., Durborow, R.M., Thune, R.L., \& Camus, A.C. 1998. ESC- Enteric Septicemia of Catfish. SRAC Publication No. 477.

Markov, G., Kirov, G., Lyutskanov, V., \& Kondarev, M. 2007 Necrotizing Fasciitis and Due to Aeromonas hydrophila. WoundISSN Vol. 19 No. 8: 223- 226.

Raghu, C., Ashok, G., Dhanaraj, S.A., Suresh, B., \& Vijayan, P. 2004. In vitro cytotoxic activity of Lantana camara Linn. Indian. Journal of Pharmacology, 36(2): 94- 95.

Taoubi, K, Fauvel, M.T., Gleye, J., \& Moulis, C. 1997. Phenylpropanoid glycosides from Lantana camara and Lippia multiflora. Planta Med, 63: 192- 3.

Wahab, A. 2004. Studies on The Chemical Constituents of Lantana camara Linn. Thesis. H.E.J Research Institute of Chemistry University of Karachi, Pakistan. 